\title{
DEPRESSIVE EFFECT OF T-2 TOXIN ON HEPATOCYTE PROLIFERATION UNDER TWO EXPERIMENTAL CONDITIONS
}

\author{
Min-Jae Lee, Makio Takeda, Kensuke Hirasawa, Shin-ichi Itagaki, and \\ Kunio Doi
}

Department of Biomedical Science, Faculty of Agriculture, The University of Tokyo

\begin{abstract}
The effect of T-2 mycotoxin on hepatocyte proliferation was investigated in mice using two models of hepatocyte regeneration, i.e. $2 / 3$ partial hepatectomy $(\mathrm{Ph})$ and $\mathrm{CCl}_{4}$-intoxication $\left(\mathrm{CCl}_{4}\right)$. At 2 days after $\mathrm{Ph}$ or $\mathrm{CCl}_{4}$, mice were given $\mathrm{T}-2$ toxin $(2$ or $4 \mathrm{mg} / \mathrm{kg}$, po). Five mice each were killed daily up to 7days after $\mathrm{Ph}$ or $\mathrm{CCl}_{4}$, and they were injected with $\mathrm{BrdU}(100 \mathrm{mg} / \mathrm{kg}$, ip) at lhour before sacrifice. $\mathrm{T}-2$ toxin significantly delayed the recovery of liver weight loss after $\mathrm{Ph}$ or $\mathrm{CCl}_{4}$, and it also significantly delayed the reduction in size of centrilobular hepatocyte necrosis after $\mathrm{CCl}_{4}$. In addition, $\mathrm{T}-2$ toxin significantly depressed BrdU-uptake by hepatocytes in the early days after $\mathbf{P h}$ or $\mathrm{CCl}_{4}$. It can be said that T-2 toxin depressed the proliferation of hepatocytes, resulting in the delay of recovery of liver weight loss. This seems to be related to the inhibitory effect of $\mathrm{T}-2$ toxin on nuclear acid synthesis of hepatocytes. (J Toxicol Pathol $7: 449 \sim 454,1994$ )
\end{abstract}

Key words : $\mathrm{BrdU}, \mathrm{CCl}_{4}$, Hepatocyte proliferation, Mouse, Partial hepatectomy, T-2 toxin

\section{Introduction}

T-2 toxin $[3 \alpha$-hydroxy-4 $\beta, 15$-diacetoxy-8$\alpha$ (3 methylbutyryloxy)-12, 13-epoxytrichothec-9ene] is a member of trichothecene mycotoxins produced by Fusarium species ${ }^{1,2}$. This toxin has radiomimetic $^{3}$ as well as immunosuppressive effects $^{4}$ and affects actively dividing cells in the gastrointestinal mucosa and lymphoid and hematopoietic tissues in many animal species. In addition, it is well known that $\mathrm{T}-2$ toxin could induce degenerative changes in the liver in some animal species including mice and rats ${ }^{5-7}$. However, there are only few reports on the effect of $T$ 2 toxin on hepatocyte proliferation. In this regard, liver regeneration is proposed to be a good system for studying cell proliferation ${ }^{8}$.

This study was carried out to clarify the effect of T-2 toxin on hepatocyte proliferation using two

李 旻宰 武田真記夫 平澤健介 板垣傎一 土井邦雄 Accepted for publication : August 7, 1994

Mailing address : Min-Jae Lee, Department of Biomedical Science, Faculty of Agriculture, The University of Tokyo, Bunkyo, Tokyo 113, Japan. experimental models of liver regeneration, i.e. partial hepatectomy and $\mathrm{CCl}_{4}$-intoxication. Administration of T-2 toxin after partial hepatectomy or $\mathrm{CCl}_{4}$-intoxication was done 2 days after those treatments based on the results of preliminary examinations.

\section{Materials and Methods}

\section{Animals}

One hundred and ninety-five 5-week-old ICR : CD-1 male mice weighing $25-30 \mathrm{~g}$ were purchased from Charles River Japan Inc. The animals were housed in an isolator caging system (Niki Shoji Co.) in an air conditioned animal room (temperature; $23 \pm 2^{\circ} \mathrm{C}$, relative humidity; $55 \pm 5 \%$ ) and fed commercial pellets, MF (Oriental Yeast Co. Ltd.) and water ad libitum throughout the experimental period.

\section{Chemicals}

T-2 toxin (Sigma Chemicals) dissolved in 20\% ethanol in phosphate buffered saline (PBS), $\mathrm{CCl}_{4}$ 
(Wako Pure Chemical Industry Co. Ltd.) in olive oil, and 5-bromo-2'-deoxyuridine (BrdU) (Sigma Chemicals) in $0.5 \mathrm{~N} \mathrm{NaHCO}_{3}$ were used.

\section{Experimental design and treatment}

Experiment 1: Partial hepatectomy (Ph) was done on 90 animals (weighing $25.6 \pm 0.98 \mathrm{~g}$ ). Namely, two-third of the liver was surgically removed under ether anesthesia according to the method of Higgins and Anderson ${ }^{8}$. Ten animals which died during the first 2 days were excluded from the experiment. At 2 days after $\mathrm{Ph}, 50$ animals were orally given T-2 toxin ( 2 or $4 \mathrm{mg} / \mathrm{kg}$ b.w.) and 30 animals solvent alone, respectively. Five animals each were killed by exanguination under ether anesthesia as scheduled up to 7 days after $\mathrm{Ph}$. At one hour before sacrifice, the animals were given $100 \mathrm{mg} / \mathrm{kg}$ b.w. of BrdU intraperitoneally. In addition, 5 animals each were killed on the first and the last day of experiment and used as non-treated controls.

The dose of $\mathrm{T}-2$ toxin was decided based on the results of preliminary acute toxicity studies, in which $4 \mathrm{mg} / \mathrm{kg}$ of $\mathrm{T}-2$ toxin did not cause any degenerative changes in hepatocytes.

Experiment 2: Eighty five animals (Weighing $27.3 \pm 1.21 \mathrm{~g}$ ) were orally given $1 \mathrm{ml} / \mathrm{kg} \mathrm{b} . \mathrm{w}$. of $\mathrm{CCl}_{4}$. Two days later, 50 animals were orally given T-2 toxin ( 2 or $4 \mathrm{mg} / \mathrm{kg}$ b.w.) and 35 animals solvent alone, respectively. Five animals each were killed as scheduled in the same way. In addition, 5 animals each were killed on the first and last day of experiment and used as non-treated controls.

\section{Liver histopathology and BrdU nuclear labeling}

Immediately after macroscopic examination, the liver was weighed and then fixed in $10 \%$ neutral buffered formalin.

Paraffin sections $(4 \mu \mathrm{m})$ were stained with hematoxylin and eosin (HE) for histopathology or with BrdU immunohistochemistry.

Morphometry of hepatocyte proliferation and necrotic area

Morphometrical analysis was done using an image analyzer, SP500 (Olympus Co. Ltd.). Namely, in Experiment 1 and 2, randomly chosen
2,000 hepatocytes were scored for BrdU labeling on each specimen and the results were expressed as the percentage labeling index (LI), and mean LI was calculated.

In addition, in Experiment 2, the area of $\mathrm{CCl}_{4}$-induced centrilobuar hepatocyte necrosis in five hepatic lobules was calculated on each specimen, and mean area was calculated.

\section{Statistical analysis}

All values are expressed as mean $\pm \mathrm{SD}$, and statistical analysis was performed by use of the Student's $t$-test.

\section{Results}

\section{Experiment 1}

As compared with the Ph-group, the body weight gain was depressed in $\mathrm{Ph}+\mathrm{T}-2$ toxin groups throughout the experimental period (Fig. 1).

At 4 days after $\mathrm{Ph}$, the liver weight almost returned to the preoperation value, showing the most steep increase from 3 to 4 days after Ph (Fig. 2). In contrast, the recovery of liver weight loss showed a significant delay of 2 to 3 days in the

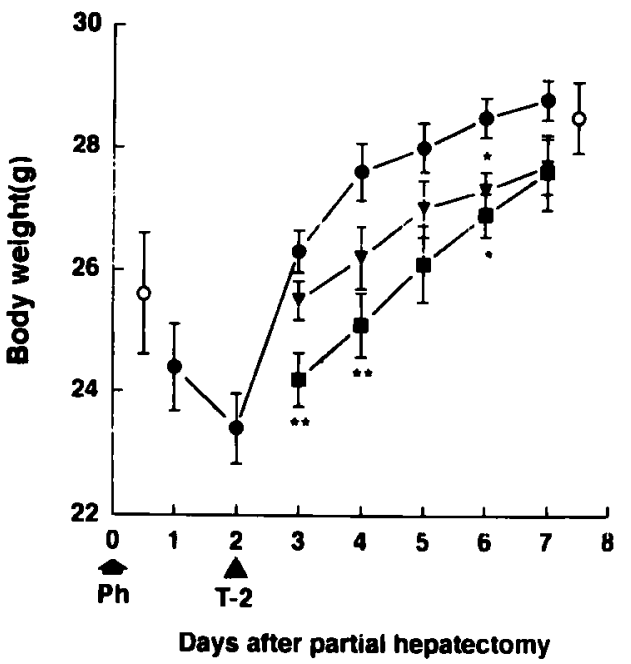

Fig. 1. Changes in body weight. Values are expressed as mean $\pm \mathrm{SD}$. **** Significantly different from $\mathrm{Ph}$-group $\left({ }^{*} ; \mathrm{P}<\right.$ $\left.0.05,^{* *} ; \mathrm{P}<0.011^{* * *} ; \mathrm{P}<0.001\right)$.

$\mathrm{O}:$ Control, $\bullet: \mathrm{Ph}-\mathrm{group}, \boldsymbol{\nabla}: \mathrm{Ph}+\mathrm{T}-2$ toxin (2 $\mathrm{mg} / \mathrm{kg}$ )-group, $: \mathrm{Ph}+\mathrm{T}-2$ toxin $(4 \mathrm{mg} / \mathrm{kg}$ )group. 


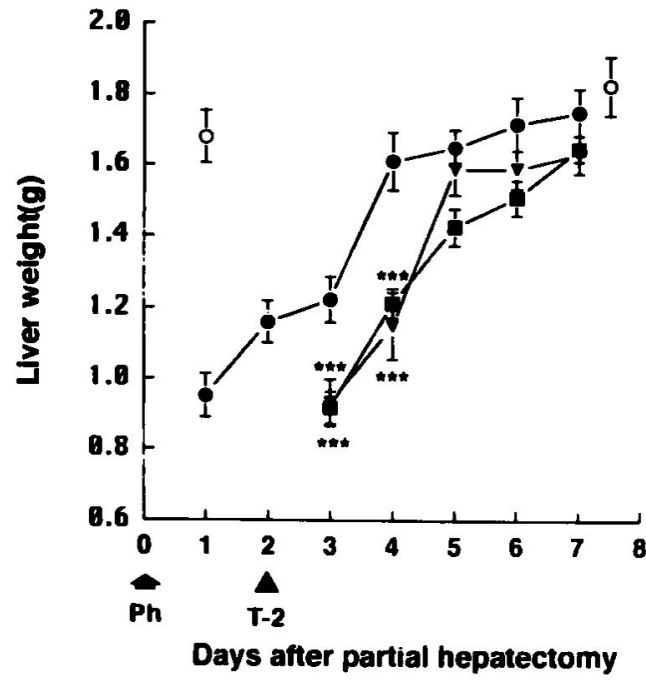

Fig. 2. Changes in liver weight. (See the foot note of Fig. 1.)

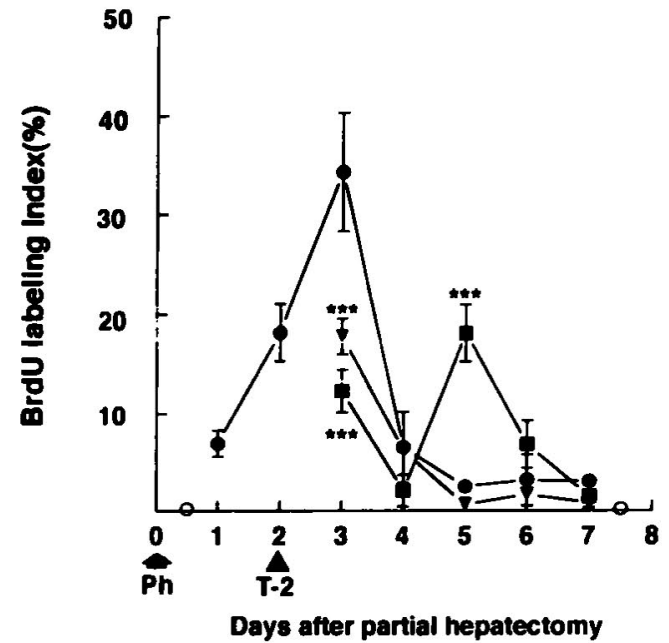

Fig. 3. Changes in BrdU labeling index of hepatocytes.

(See the foot note of Fig. 1.)

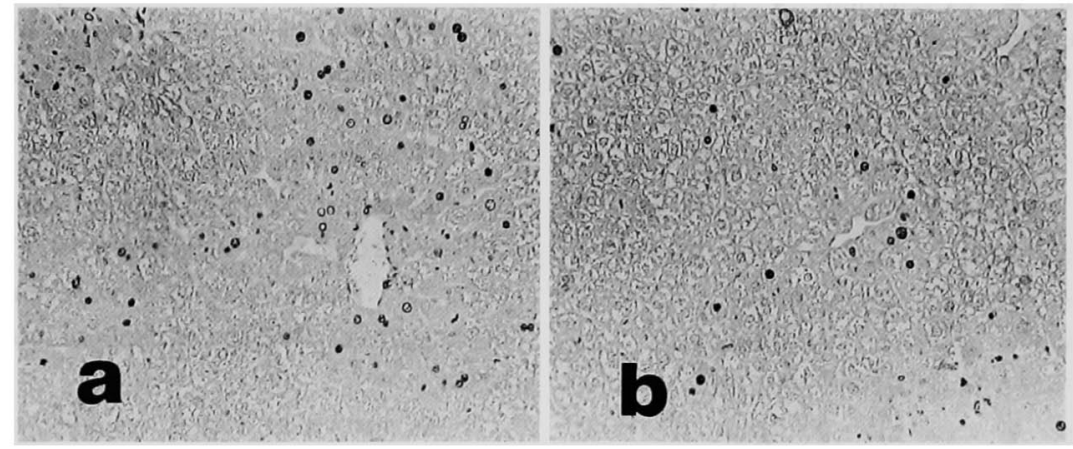

Fig. 4. Liver at 3 days. BrdU immunohistochemistry, $\times 150$.

a) Ph-group. Many BrdU-positive hepatocytes (dark nuclei) are seen.

b) $\mathrm{Ph}+\mathrm{T}-2$ toxin $(4 \mathrm{mg} / \mathrm{kg}$ )-group. BrdU-positive hepatocytes are fewer than those in a).

$\mathrm{Ph}+\mathrm{T}-2$ toxin-groups as compared with the $\mathrm{Ph}-$ group (Fig. 2).

As shown in Fig. 3, hepatocyte LI increased rapidly following $\mathrm{Ph}$ and reached its peak at 3 days. Then, it declined at 4 days to the level similar to that at 1 day. At 3 days after $\mathrm{Ph}$, hepatocyte LI was apparently lower in a dosedependent manner in the $\mathrm{Ph}+\mathrm{T}-2$ toxin-groups than in the Ph-group (Figs. 3 and 4). After that, there was no significant difference in hepatocyte $\mathrm{LI}$ between $\mathrm{Ph}$-group and $\mathrm{Ph}+\mathrm{T}-2$ toxin $(2 \mathrm{mg} / \mathrm{kg}$ )group. However, in the $\mathrm{Ph}+\mathrm{T}-2$ toxin $(4 \mathrm{mg} /$ $\mathrm{kg}$ )-group, hepatocyte LI reincreased transiently at 5 days after $\mathrm{Ph}$ (Fig. 3).
There was no apparent evidence of degenerative changes of hepatocytes due to $\mathrm{T}-2$ toxin.

\section{Experiment 2}

As compared with the $\mathrm{CCl}_{4}$-group, the body weight gain was depressed in the $\mathrm{CCl}_{4}+\mathrm{T}-2$ toxin groups throughout the experimental period (Fig. 5).

The liver weight almost returned to the pretreatment value at 2 days after $\mathrm{CCl}_{4}$-intoxication and it reached a plateau one day later (Fig. 6). In the $\mathrm{CCl}_{4}+\mathrm{T}-2$ toxin-groups, the recovery of liver weight loss showed a significant delay of 3 to 4 days as compared with the $\mathrm{CCl}_{4}$-group (Fig. 6). 


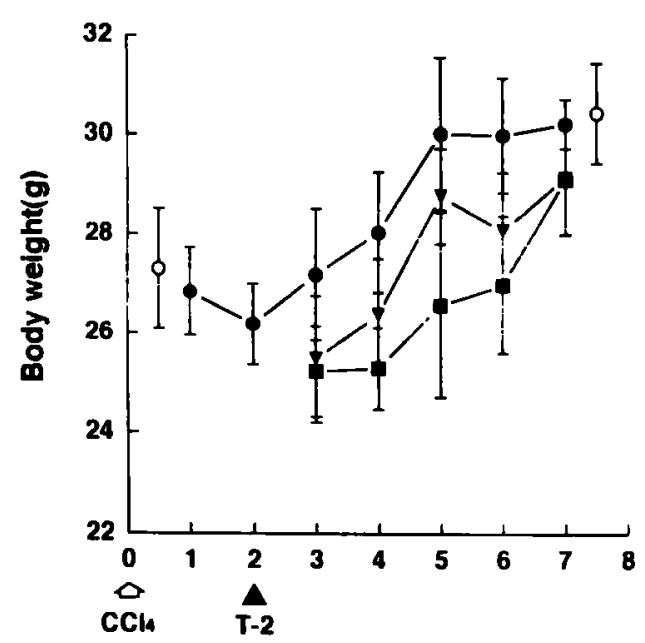

Days after CCla-intoxication

Fig. 5. Changes in body weight.

Values are expressed as mean $\pm \mathrm{SD}$.

*-***Significantly different from $\mathrm{CCl}_{4}$-group (* ; $\left.\mathrm{P}<0.05,{ }^{* *} ; \mathrm{P}<0.01, * * * \mathrm{P}<0.001\right)$.

$\mathrm{O}$ : Control, $\bullet: \mathrm{CCl}_{4}$-group, $\nabla: \mathrm{CCl}_{4}+\mathrm{T}-2$ toxin $(2 \mathrm{mg} / \mathrm{kg})$-group, $\mathbf{a}: \mathrm{CCl}_{4}+\mathrm{T}-2$ toxin $(4$ $\mathrm{mg} / \mathrm{kg}$ )-group.

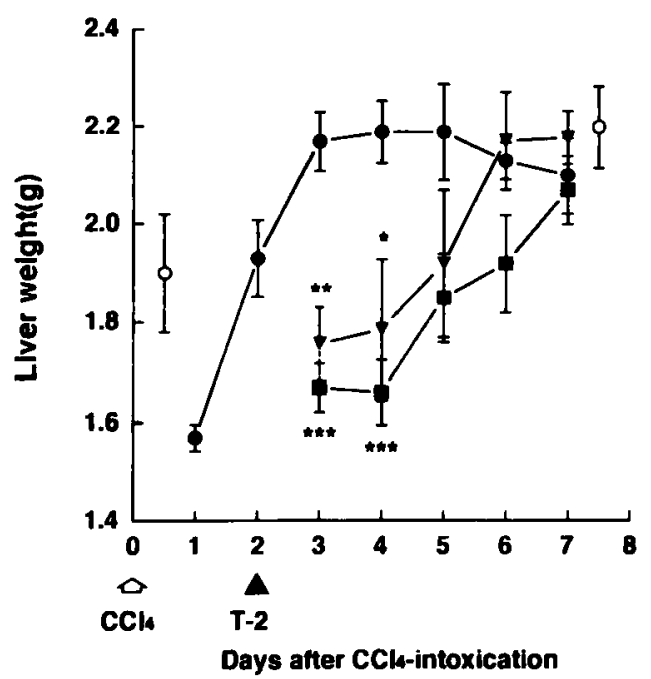

Fig. 6. Changes in liver weight. (See the foot note of Fig. 5)

Histopathologically, marked centrilobular coagulative necrosis of hepatocytes developed at 1 day after $\mathrm{CCl}_{4}$-intoxication. After that, necrotic area reduced day by day and almost disappeared at 7 days after $\mathrm{CCl}_{4}$-intoxication (Fig. 7). In the $\mathrm{CCl}_{4}+\mathrm{T}-2$ toxin $(4 \mathrm{mg} / \mathrm{kg}$ )-group, a reduction in

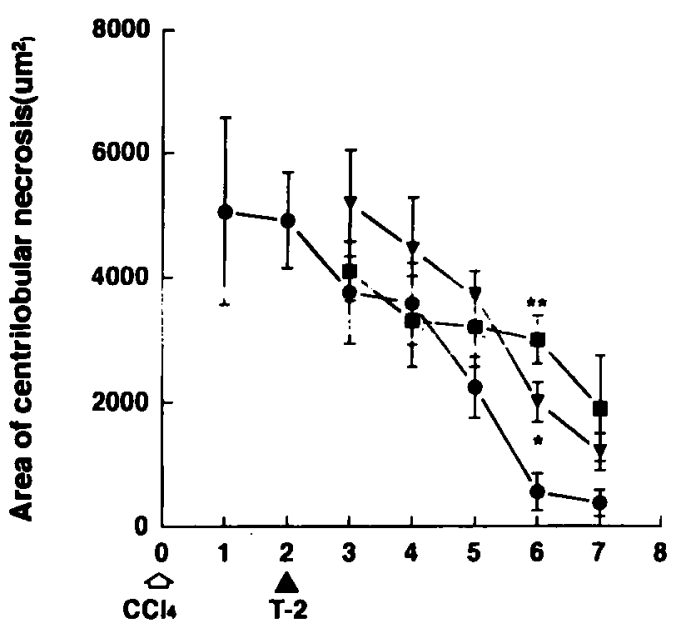

Days after CCla-intoxication

Fig. 7. Changes in necrotic area after $\mathrm{CCl}_{4}$-intoxication.

(See the foot note of Fig. 5.)

necrotic area was significantly delayed throughout the experimental period (Figs. 7 and 8) as compared with the $\mathrm{CCl}_{4}$-group.

On the other hand, in the $\mathrm{CCl}_{4}+\mathrm{T}-2$ toxin (2 $\mathrm{mg} / \mathrm{kg}$ )-group, a reduction in necrotic area was delayed from 5 to 7 days after $\mathrm{CCl}_{4}$-intoxication (Fig. 7). There was no apparent evidence of degenerative changes of hepatocytes due to $T-2$ toxin.

As shown in Fig. 9, hepatocyte LI increased rapidly and reached its peak already at 1 day after $\mathrm{CCl}_{4}$-intoxication. After that, it declined rapidly to the level similar to that of non-treated controls at 5 days after $\mathrm{CCl}_{4}$-intoxication. On the other hand, hepatocyte $\mathrm{LI}$ was lower in the $\mathrm{CCl}_{4}+\mathrm{T}-2$ toxin-groups at 3 and 4 days after $\mathrm{CCl}_{4}$-intoxication (Figs. 9 and 10).

\section{Discussion}

In the present study, we, for the first time, examined the effect of $\mathrm{T}-2$ toxin on hepatocyte proliferation using two models of hepatocyte regeneration, i.e. partial hepatectomy and $\mathrm{CCl}_{4}-$ intoxication in mice.

In Experiment 1, changes in the liver weight and hepatocyte LI after partial hepatectomy were similar to those previously reported in mice and rats $^{10}$. Following $\mathrm{T}-2$ toxin-treatment, the recov- 


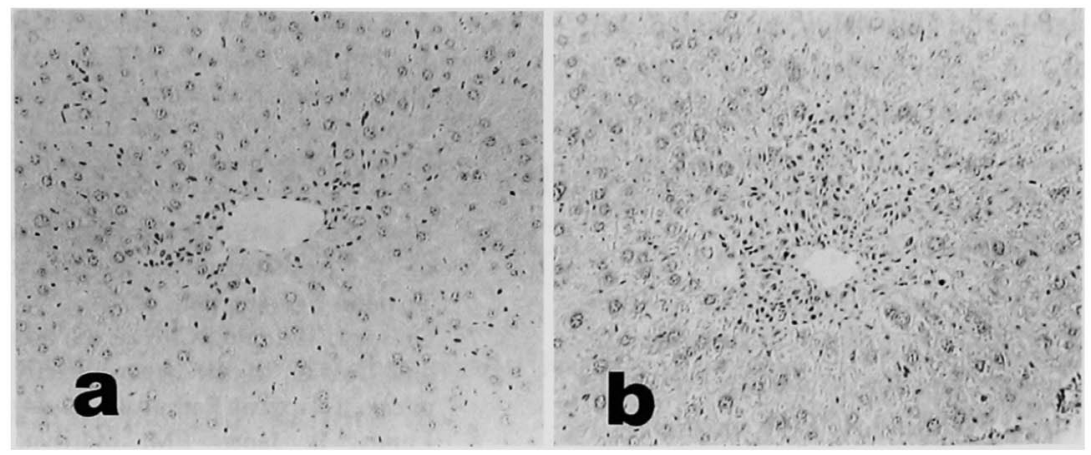

Fig. 8. Liver at 7 days. HE, $\times 150$.

a) $\mathrm{CCl}_{4}$-group. Necrotic area is almost undetectable.

b) $\mathrm{CCl}_{4}-\mathrm{T}-2$ toxin $(4 \mathrm{mg} / \mathrm{kg})$-group. Reduction in necrotic area is delayed.

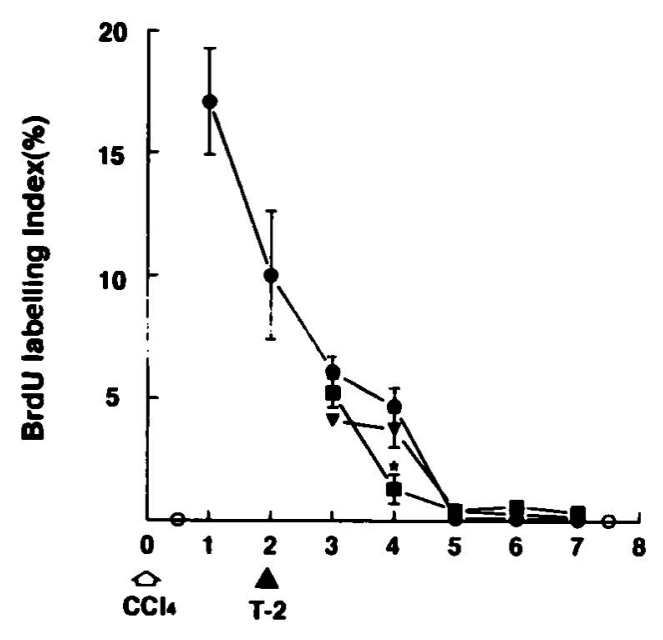

Days after CCla-intoxication

Fig. 9. Changes in BrdU labeling index of hepatocytes.

(See the foot note of Fig. 5.) ery of liver weight loss was delayed, and this delay seems to correlate with the prominent decrease in hepatocyte LI at 1 day after T-2 toxin-treatment, i.e. 3 days after $\mathrm{Ph}$ when hepatocyte $\mathrm{LI}$ reached its peak in $\mathrm{Ph}$-group. However, the cause for reincrease of hepatocyte LI transiently observed at 3 days after $\mathrm{T}-2$ toxin-treatment in the $\mathrm{Ph}+\mathrm{T}-2$ toxin $(4 \mathrm{mg} / \mathrm{kg})$-group is still obscure.

In Experiment 2, hepatocyte LI very quickly increased and reached its peak already at 1 day after $\mathrm{CCl}_{4}$-intoxication and then decreased rapidly. This seems to contribute to the relatively fast recovery of liver weight loss after $\mathrm{CCl}_{4}$-intoxication. In addition, the area of centrilobular hepatocyte necrosis was reduced to a very small size at 7 days after $\mathrm{CCl}_{4}$-intoxication as reported previously ${ }^{11}$.

Following T-2 toxin-treatment, the recovery of liver weight loss brought about by $\mathrm{CCl}_{4}$-intoxi-

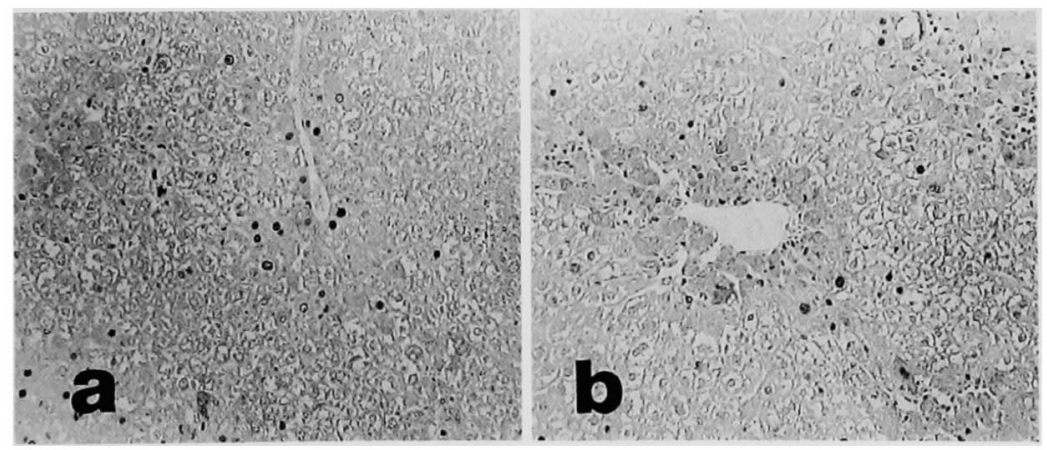

Fig. 10. Liver at 4 days. BrdU immunohistochemistry, $\times 150$.

a) $\mathrm{CCl}_{4}$-group. Many BrdU-positive hepatocytes are seen.

b) $\mathrm{CCl}_{4}+\mathrm{T}-2$ toxin $(4 \mathrm{mg} / \mathrm{kg})$-group. BrdU-positive hepatocytes are fewer than those in a). 
cation was delayed, and this delay correlated well with the delay in the reduction in area of centrilobular hepatocyte necrosis. These changes in turn seem to be based on the decrease in hepatocyte LI at 1 or 2 days after $T-2$ toxin-treatment, i.e. 3 or 4 days after $\mathrm{CCl}_{4}$-intoxication.

Being common to Experiments 1 and 2, there was no apparent evidence of degenerative changes of hepatocytes due to T-2 toxin, and the delay in the recovery of liver weight loss both in the $\mathrm{Ph}+$ $\mathrm{T}-2$ toxin-group and in the $\mathrm{CCl}_{4}+\mathrm{T}-2$ toxingroup is considered to be brought about by an inhibitory effect of $\mathrm{T}-2$ toxin on nuclear acid synthesis of hepatocytes ${ }^{12-14}$, resulting in a depression of hepatocyte proliferation as indicated by the decrease in hepatocyte LI as mentioned above.

Now, we are investigating the effect of $\mathrm{T}-2$ toxin on the normal cell cycle of hepatocytes in mice.

\section{References}

1. Bumburg, JR, Riggs, NV, and Strong, FM: The structures of toxins from two strains of Fusarium tricinctum. Tetrahedron $24: 3329-3336,1968$.

2. Hsu IC, Samlley EB, Strong, FM : Identification of T-2 toxin in moldy corn associated with lethal toxicosis in dairy cattle. Appl Microbiol 24: 684690, 1972.

3. Ueno, Y.: Toxicology. In: Trichothecenes-chemical, biological and toxicological aspects, Y Ueno Ed, Elsevier, Amsterdam, 1983.

4. Ueno, Y, Ishii, K, Sakai, K, Knaeda, S, Tsunoda, H, Tanaka, T, and Enomoto, M.: Toxicological approaches to the metabolites of fusaria. IV. Microbial survey on "Bean-Hulls poisoning of horses" with the isolation of toxic trichothecenes, neosolaniol and T-2 toxin of Fusarium solani M-11. Jpn Exp Med 42 : 187-203, 1972.

5. Min-Jae Lee, Kawamura, S, Itagaki, S and Doi, K : Toxic effects of $\mathrm{T}-2$ toxin on the primary hepatocyte culture from mice. J Toxicol Pathol 7: 43-50, 1994.

6. Trusal, LR, and O'Brien, JC : Ultrastructural effects of T-2 mycotoxin on rat hepatocytes in vitro. Toxicon 24: 481-488, 1986.

7. Quiroga, MA, Doi, C, Han, JS, Akai, H, Tamura, K. and Doi, $K$ : Acute hepatotoxicity of $T-2$ toxin in mice. J Toxicol Pathol 4 : 35-44, 1991

8. Lundy, B, Janet, EM, Marilyn, P, Ryoko, M, Graeme, JB, and Nelson, F : Transforming growth factor $\beta$ m-RNA increases during liver regeneration: A possible paracrine mechanism of growth reguration. Proc Natl Assoc Sci 85: 1539-1543, 1988.

9. Higgns, GM and Anderson, RM: Experimental pathology of the liver. Arch Path 12: 186-202, 1931.

10. Noguchi, S, Ohba, Y, and Oka $T$ : The role of transcription and messenger RNA stability in the regulation of epidermel growth factor receptor gene expression in regeneration mouse liver. Hepatology 15 : 88-96, 1992.

11. Bhathal, PS, Rose, NR, Mackay IR and S. Whittingham : Strain differences in mice in carbon Tetrachloride-induced liver Injury. Br J Exp Path 64: 524-533, 1983.

12. Tashiro, $\mathrm{F}$, Hirai, $\mathrm{K}$ and Ueno $\mathrm{Y}$ : Inhibitory effects of carcinogenic mycotoxins on deoxyribonucleic acid dependent ribonucleic acid polymerase and ribonulease H. : Appl Environ Microbiol 38 : 191196, 1979.

13. Thompson, WL and Wannemacher, JR: Detectin and quantitation of $T-2$ mycotoxin with a simplified protein syntheisis inhibition assay. Appl Environ Microbiol 48: 1176-1180, 1984.

14. Rosenstein, $Y$ and Lafarge-Frayssinet, $C$ : Inhibitory effect of Fusarium T-2 toxin on lymphoid DNA and protein synthesis. Toxicol Appl Pharmacol 70 : 283-288, 1983. 